\title{
DINAMIKA MAHASISWA DALAM MEMBANGUN CITRA KAMPUS RELEGIUS DI SULAWESI SELATAN
}

\author{
Oleh: Abd. Kadir M
}

\begin{abstract}
Abstrak
Penelitian ini bersifat deskriptif kualitatif. Data diperoleh dengan menggunakan metode wawancara dan observasi. Penelitian yang berlokasi di beberapa perguruan tinggi di Sulawesi Selatan ini bertujuan untuk menggambarkan aktivitas-aktivitas dan pandangan-pandangan kelompok keagamaan di tingkat mahasiswa dalam upaya membangun citra kampus religius.

Hasil penelitian menunjukkan, bahwa kegiatan dan aktivitas kelompok-kelompok keagamaan itu berdasar pada dua orientasi, yaitu internal dan eksternal. Orientasi internal bertujuan untuk penguatan organisasi dengan melakukan kegiatanpelatihan dan pengkaderan, sedangkan orientasi eksternal bertujuan mempengaruhi pemikiran keagamaan yang berkembang berdasarkan misi dan tujuan organisasi dengan melakukan berbagai kajian, seminar, dan bedah buku.Pandangan kelompok-kelompok keagamaan menyangkut berbagai aspek ajaran Islam dan aspek kehidupan manusia dengan tidak terlepas dari faktor-faktor yang melatarbelakangi keberadaannya. Berdasarkan tema-tema kajian yang berkembang, kelompok-kelompok keagamaan tersebut dapat dibagi pada tiga kelompok: Pertama, kelompok yang semata-mata menyampaikan ajaran Islam dalam rangka untuk memberikan keseimbangan sikap dalam kehidupan ini. Kedua, kelompok yang ingin melakukan pemurnian terhadap ajaran agatna berdasarkan Alquran dan hadis. Ketiga, kelompok yang ingin melakukan islamisasi seluruh kehidupan manusia, untuk membentuk suatu masyarakat berdasarkan ajaran Islam.
\end{abstract}

\section{PENDAHULUAN}

\section{A. Latar Belakang}

Kehidupan agama Islam dengan munculnya kelompok-kelompok keagamaan di berbagai perguruan tinggi umum di Indonesia memperlihatkan kecendrungan semakin meningkat dari tahun ke tahun. Hal itu disebabkan oleh munculnya arus besar kebangkitan spiritual yang melanda generasi muda, terutama di kalangan mahasiswa, khususnya mahasiswa Islam. Sebagaimana dikatakan oleh Burger, agama memberi legitimasi bagi penganutnya secara efektif, karena ia mengkonstruksikan realitas yang sering tidak menentu dengan mengaitkannya dengan realitas tertinggi. Tidak hanya sekedar sebagai alat untuk mempertahankan stabilitas tatanan sosial, tetapi sekaligus menjadi analisis terhadap berbagai fakta sosial dan peristiwa- 
peristiwa sosial yang ditemukan oleh penganutnya dalam kurun kehidupan mereka.

Kebangkitan kelompok-kelompok kegamaan di kalangan mahasiswa, bukan semata-mata sebagai jawaban akan kerinduan terhadap stabilitas, kedamaian dan upaya memenuhi kebutuhan akan kerinduan terhadap nilainilai keagamaan, melainkan juga menjadi sarana untuk melakukan perlawanan terhadap ketidakadilan yang dilakukan oleh penguasa. Pada masa pemerintahan Orde Baru, gejala-gejala korupsi, kolusi, dan nepotisme demikian merajalela yang berakibat demikian dahsyat, ditandai oleh krisis multidimensional, krisis moneter, moral dan krisis kepercayaan. Ternyata, fenomena ini tidak berhenti ketika pemerintahan Orde Baru tumbang tahun 1998, yang kemudian berganti dengan era reformasi. Hal ini membuat rakyat semakin terpuruk dalam kemiskinan dan ketidakberdayaan.

Di beberapa negara berkembang, termasuk Indonesia, ketimpanganketimpangan sosial seringkali membuka peluang bagi lahirnya sebuah krisis. Hal ini kemudian memunculkan kekuatan-kekuatan pendobrak terhadap ketidakadilan. Kelompok pendobrak ini biasanya muncul dari kalangan kelompok-kelompok mahasiswa sebagai komponen yang senantiasa membela kepentingan rakyat. Fachry Ali dan Bachtiar Effendy menyebutnya, mahasiswa lebih merupakan kekuatan siap pakai.

Bagi mahasiswa Islam, penentangan terhadap ketidakadilan memperoleh p'embenaran karena Islam juga dapat menjadi sebuah ideologi politik, bukan sekedar mengurusi kehidupan pribadi manusia Islam, karenanya mendorong umatnya untuk secara terus menerus merealisasikan doktrindoktrin keagamaannya itu secara terus menerus ke dalam seluruh aspek kehidupan manusia. Bahkan menurut Al-Banna, dalam Islam, pemuda dianggap memiliki peran penting untuk memobilisasikan kesadaran masyarakatnya. Pemuda adalah pilar kebangkitan, dan dalam setiap kebangkitan, pemuda merupakan rahasia kekuatannya. Sudah barang tentu, pemuda yang menjadi harapan adalah pemuda yang terpelajar yang memiliki wawasan yang luas serta nurani untuk memperbaiki kebobrokan dan ketidakadilan.

Kebangkitan kelompok-kelompok keagamaan mahasiswa tidak terlepas dari keberadaan musala dan mesjid kampus sebagai sarana untuk melakukan dialog-dialog keagamaan, keilmuan, masalah sosial sampai kepada masalah politik. Karena itu, mesjid kampus dapat dilihat sebagai basis pengembangan agama Islam, sarana dialog agama dan ilmu pengetahuan dan basis perlawanan sosial politik. 
Atas dasar alasan-alasan di atas itulah diperlukan suatu penelitian tentang isu-isu sosial keagamaan, khususnya dinamika mahasiswa dalam membangun citra kampus religius.

\section{B. Rumusan Masalah}

a. Bagaimana dinamika mahasiswa dalam membangun kelompok-kelompok keagamaan di kampus?

b. Bagaimana aktivitas kelompok-kelompok keagamaan itu?

c. Bagaimana pandangan kelompok-kelompok keagamaan terhadap berbagai aspek kehidupan?

\section{Tujuan dan Signifikansi Penelitian}

Penelitian ini bertujuan: 1) Untuk mengetahui dinamika mahasiswa dalam membangun kelompok-kelompok keagamaan di kampus, 2) untuk mengetahui aktivitas kelompok-kelompok keagamaan itu, dan 3) untuk mengetahui pandangan kelompok-kelompok keagamaan terhadap berbagai aspek kehidupan.

Sedangkan signifikansi dari penelitian ini, yaitu diharapkan hasilnya dapat dijadikan bahan masukan bagi perumusan dan pengambilan kebijakan bagi Departemen Agama dan Departemen Pendidikan Nasional dalam rangka pembinaan kehidupan keagamaan generasi muda, khususnya kalangan mahasiswa secara lebih konstruktif sehingga memungkinkan terjadinya stabilitas yang kondusif bagi pembangunan nasional. Selain itu, melalui penelitian seperti ini diharapkan dapat memberikan informasi yang lebih luas dan mendalam terhadap kehidupan beragama di kalangan mahasiswa.

\section{Dejinisi Operasional}

1. Dinamika Mahasiswa, mengacu pada pemahaman tentang proses yang digerakkan oleh hubungan-hubungan personal intra dan antar mahasiswa, termasuk otoritas kampus maupun pihak-pihak di luar kampus yang secara bersama-sama terlibat dalam pengelolaan aktivitas sosial, politik, keilmuan, dan agama (Islam).

2. Citra kampus religius, adalah sebuah kampus yang ditandai oleh munculnya nuangsa dialogis antara konsep-konsep teoritis ilmu-ilmu empiris dengan konsep-konsep normatif agama (Islam).

3. Dialog, mengacu pada pengertian tentang olah pikir berkenaan dengan sebuah wacana pikir berkenaan dengan sebuah wacana tentang dimensi 
keilmuan dan keagamaan (Islam) di kalangan mahasiswa di kampuskampus Perguruan Tinggi.

\title{
E. Kerangka Konseptual
}

\author{
Dinamika Mahasiwa \\ Kelompok-kelompok \\ keagamaan \\ Mesjid/mushalla kampus
}

Dimensi keagamaan

Dimensi keilmuan
politik

Citra kampus religius

(Agamais-Islam)

\section{E. Metode Penelitian}

1. Lokasi dan Sasaran Penelitian

Penelitian ini dilaksanakan di Propinsi Sulawesi Selatan dengan memilih secara purposif enam lembaga perguruan tinggi umum, baik negeri maupun swasta. Keenam perguruan tinggi itu adalah: Universitas Hasanuddin (Unhas) Makassar, Universitas Negeri Makassar (UNM), Sekolah Tinggi Keguruan dan Ilmu Pendidikan (STKIP) DDI di Kabupaten Polmas, Sekolah Tinggi Keguruan dan Ilmu Pendidikan (STKIP) Cokroaminoto di Kota Palopo, Sekolah Tinggi Keguruan dan Ilmu Pendidikan (STKIP) Puangrimagalatung di Sengkang, Sekolah Tinggi Keguruan dan Ilmu Pendidikan (STKIP) dan Sekolah Tinggi Ilmu Ekonomi (STIE) Yayasan Pendidikan Turatea Indonesia (YAPTI) di Jeneponto.

\section{Teknik Pengumpulan Data}

Dalam penelitian ini, teknik pengumpulan data yang dipergunakan adalah studi kepustakaan, wawancara, dan pengamatan. Studi kepustakaan, yaitu mempelajari tulisan-tulisan yang berkaitan dengan masyarakat dan 
kebudayaan manusia yang menjadi sasaran penelitian, serta dokumendokumen perguruan tinggi yang diteliti. Wawancara mendalam dengan beberapa informan yang terdiri atas pejabat otoritas kampus, pemimpin kelompok keagamaan mahasiswa, anggota kelompok keagamaan mahasiswa, dan staf pengajar mata kuliah Pendidikan Agama Islam. Pengamatan dilakukan terhadap kegiatan dan kajian keagamaan mahasiswa, baik di dalam maupun di luar kampus.

\section{Analisis Data}

Dengan menggunakan pendekatan kualitatif, analisis yang digunakan dalam penelitian ini berpegang pada prinsip penelitian kualitatif, yaitu pengumpulan, pengolahan dan analisis data dilakukan secara bersamaan selama proses penelitian. Proses analisis data dimulai dengan menelaah data yang tersedia dalam berbagai sumber, yaitu wawancara, pengamatan dan penelusuran pustaka dan dokumen. Penelaahan data dilakukan dengan cara membaca dan mempelajari secara seksama untuk menentukan relevansi antara data yang diperoleh dengan permasalahan yang diteliti. Keseluruhan data dikelompokkan kemudian diinterpretasi dan disusun dalam bentuk pernyataan-pernyataan.

\section{HASIL PENELITIAN}

\section{A. Identifikasi Perguruan Tinggi yang Diteliti}

\section{Universitas Hasanuddin (Unhas) Makassar}

Universitas Hasanuddin Makassar adalah salah satu universitas negeri yang tertuadi Indonesia bagian timur, didirikan dan diresmikan oleh Muhammad Hatta, wakil presiden Republik Indonesia pertama pada tanggal 10 September 1956. Nama Hasanuddin yang di berikan pada nama lembaga perguruan tingg $i$ ini diambil dari nama Raja Gowa yang ke 16 yaitu I Mallombasi Daeng Mattawang Karaeng Bontomangape Sultan Hasanuddin. Raja ini diberi gelar oleh penjajah Belanda dengan ayam jantan dari timur, sehingga lambang Unhas adalah seekor ayam jantan yang sedang berkokok berpaling kekanan dengan kedua sayap yang dikembangkan.

Pada awal berdirinya, Unhas hanya terdiri dari empat fakultas yaitu Fakultas Kedokteran, Hukum, Ekonomi dan Fakultas Keguruan dan Ilmu Pendidikan. Antara tahun 1960-1964, Unhas membuka enam fakultas baru, yaitu Fakultas Tehnik, Sastra, Sospol, Pertanian, MIPA, dan Fakultas Petemakan. 
Pada tahun 1981, Unhas menempati kampus di Tamalanrea yang diresmikan oleh Soeharto Presiden Republik Indonesia bertepatan hari ulang tahun Unhas yang ke-25. Dua tahun kemudian setelah peresmian kampus baru dua fakultas baru dibuka yaitu Fakultas Kesehatan Masyarakat dan Fakultas Kedokteran Gigi dan pada tahun 1996 Unhas menambah satu fakultas yaitu Fakultas Kelautan dan Perikanan.

Setiap tahun Unhas selalu mengembangkan diri dengan mengadakan inovasi baru untuk dapat bersaing dengan perguruan tinggi di Jawa, Untuk pengembangan tersebut Unhas membuka program-program baru. Dan sampai saat ini Unhas telah mempunyai 12 Fakultas, 53 program sarjana (SI), 23 program Magister (S2), 8 prgram Doktor (S3) dan 14 program Diploma. Dengan program-program studi yang dibuka tersebut semakin mengundang minat masyarakat, sehingga tidak dapat menampung semua pendaftar, dan untuk mengatasi hal tersebut Unhas mengadakan seleksi penerimaan mahasiswa baru dengan ketat.

\section{Universitas Negeri Makassar (UNM)}

Universitas Negeri Makassar berdiri dengan status mandiri pada tanggal 5 Januari 1965 dengan nama Institut Keguruan dan Ilmu Pendidikan (IKIP) Makassar. Sejak berdirinya, UNM sudah beberapa kali mengalami pergantian dan perubahan nama sejalan dengan perkembangan masyarakat, ilmu pengetahuan dan teknologi. Pada mulanya, UNM diberi nama dengan IKIP Makassar, dan pada tahun 1972, IKIP Makassar berubah menjadi IKIP Ujung pandang dengan mengikuti perubahan nama Kotamadya Makassar menjadi Kotamadya Ujungpandang, Pada tahun 1999 IKIP Ujung Pandang berubah status menjadi Universitas Negeri Makassar (UNM) berdasarkan SK Presiden Republik Indonesia No. 93 Tahun 1999 tanggal 4 Agustus 1999.

Dengan perubahan status dari institut ke universitas, UNM tidak hanya sebagai perguruan tinggi yang dirancang untuk memenuhi keperluan pendidikan bagi calon-calon tenaga kependidikan yang kelak akan mengisi kebutuhan guru sekolah di seluruh Indonesia, tetapi juga dirancang untuk memenuhi kebutuhan pendidikan bagi calon-calon tenaga non kependidikan yang kelak akan mengisi kebutuhan berbagai instansi dan lembaga yang terkait dengan spesifikasi alumninya.

UNM mengelola enam fakultas dengan program studi kependidikan dan non kependidikan. Keenam fakultas tersebut adalah: 1) Fakultas Ilmu Keolahragaan (FIK) dengan tiga program studi, yakni; SI Kependidikan, 
Non Kependidikan dan Program D2. 2) Fakultas Matematika dan Ilmu Pengetahuan Alam (FMIPA) dengan dua program studi, yakni; SI Kependidikan dan Non Kependidikan. 3) Fakultas Bahasa dan Seni (FBS) dengan tigaprogram studi, yakni; SI Kependidikan, SI Non Kependidikan, dan D3 Non Kependidikan. 4) Fakultas Ilmu Pendidikan (FIP) dengan dua program studi, yakni; Program SI dan Program D2. 5) Fakultas Ekonomi dan Ilmu Sosial (FIES) dengan dua program studi, yakni; program SI Kependidikan dan program SI Non kependidikan, dan 6) Fakultas Teknik (FT) dengan dua program studi, yakni SI Kependidikan dan D3 Non Kependidikan.

Jumlah dosen yang ada di UNM sebanyak 778 orang dosen dengan kualifikasi S1 sebanyak 233 orang, S2 sebanyak 474 orang dan S3 sebanyak 71 orang, diantara mereka terdapat 39 orang guru besar. Sedang Dosen yang sementara mengikuti tugas belajar di dalam dan luar negeri S2 5 orang dan S3 54 orang, sampai pada 27 Februari 2004.

\section{Sekolah Tinggi Keguruan dan Ilmu Pendidikan (STRIP) DDI POLMAS}

STKIP DDI didirkan pada tanggal 17 Januari 1975, dan merupakan perguruan tinggi umum pertama yang didirikan oleh organisasi Darud Dakwah wal Irsyad (DDI) dan berlokasi di Polewali, ibukota Kabupaten Polmas. Berdirinya perguruan tinggi umum ini dilatar belakangi oleh beberapa faktor: 1) banyaknya alumni Sekolah Lanjutan Tingkat Atas yang ingin melanjutkan pelajarannya di perguruan tinggi, 2) membantu orang tua yang tidak mampu membiayai kuliah anak-anaknya di kota-kota besar, dan 3) kemajuan yang dicapai oleh beberapa daerah tingkat di daerah Sulawesi Selatan. STKIP membina dua program studi, yaitu Program Studi Pendidikan Moral Pancasila dan Kewarganegaraan, dan Pendidikan Bahasa dan Sastra Indonesia.

Jumlah mahasiswa pada tahun akademik 2002/2033 sebanyak 514 orang terdiri atas 446 orang program studi PPKN dan 68 orang program Bahasa Indonesia. Jumlah dosen 28 orang, terdiri atas 22 orang laki-laki dan 6 orang perempuan. Dilihat dari statusnya, dosen tersebut terdiri atas 9 orang dosen tetap yayasan, 11 orang dosen PNS yang dipekerjakan, 6 orang dosen luar biasa dari PTN Kopertis IX, dan 2 orang dosen luar biasa dari instansi pemerintah (non PTS). Dosen tersebut adalah alumni Unhas 11 orang, IKIP1 1 orang, STKIP DDI 2 orang, dan Universitas DDI Mangkoso 
1 orang, Sospol 17 Agustus 1 orang, Unsrat 1 orang dan Houston University 1 orang.

Mahasiswa yang kuliah di perguruan tinggi ini pada umumnya adalah guru dan pegawai yang memperoleh kesempatan untuk menambah pengetahuan untuk peningkatan profesinya, sedangkan jumlah mahasiswa yang bukan guru dan pegawai sangat sedikit, dan mereka adalah mahasiswa yang orang tuanya kurang mampu menyekolahkan di Makassar, atau anak yang dihawatirkan oleh orang tua terpengaruh dari pengaruh negatif kota.

Untuk memudahkan mahasiswa yang sudah bekerja sebagai PNS, dibuka kelompok belajar (pokjar) di beberapa tempat dengan jumlah mahasiswa setiap kelompok belajar itu sekitar 20 orang. Ada 8 tempat yang dibuka oleh STKIP DDI sebagai pokjar, yaitu Mamuju, Sumarorong (Mamasa), Mambi (Mamasa), Tuppu (Pinrang), Tappalang (Mamuju), Majene, Mamasa, dan Malunda (Majene). Perkuliahan secara efektif hanya dilaksanakan dua hari seminggu, yaitu hari Sabtu dan Minggu. Perkuliahan pada hari Sabtu dilaksanakan pada jam 14.00-17.00, sedangkan hari Minggu dilaksanakan pada jam 08.00-17.00. Untuk mencapai jumlah pertemnuan setiap mata kuliah yang minimal 14 kali pertemuan, maka 1 kali pertemuan perkuliahan itu, diperuntukkan untuk 3 kali pertemuan secara normal, sehingga setiap mata kuliah itu hanya dilakukan 4 kali pertemuan, setiap semester.

Agar materi dapat dikuasai mahasiswa, setiap dosen membentuk kelompok studi dan diberi tugas mendiskusikan materi kuliah, Selain itu, dosen memberikan tugas tambahan dalam bentuk penulisan makalah, kemudian dipresentasikan oleh mahasiswa.

\section{Sekolah Tinggi Keguruan dan Ilmu Pendidikan (STKIP) Cokroaminoto Palopo}

STKIP Cokroaminoto berdiri sendiri pada tahun 1976 berdasarkan SK Kopertis Wilayah VII tanggal 24 Januari 1976. Awalnya perguruan tinggi merupakan filial dari Universitas Cokroaminoto Makassar yang mengelola fakultas keguruan dan ilmu pendidikan (FKIP) yang dibentuk pada tangal 1 Maret 1967.

Sampai sekarang, STKIP mengelola tiga jurusan dengan enam program studi, yaitu Jurusan Civic Hukum dengan Program Studi PPKN, Jurusan MIPA dengan Program Studi Matematika dan IPA, dan jurusan Bahasa dan Seni dengan program studi Bahasa Indonesia dan Bahasa Inggeris, serta program studi PGSD jenjang D2. 
Sejak tahun 1968, penyelenggaraan perguruan tinggi ini dikelola oleh Yayasan Perguruan Tinggi Cokroaminoto Palopo, dan sekarang dipersiapkan Sekolah Tinggi ini berubah status menjadi Universitas. Jumlah mahasiswa STKIP Cokroaminoto tahun akademik 2003/2004 sebanyak 1.114 orang.

\section{Sekolah Tinggi Keguruan dan Ilmu Pendidikan (STKIP) Puang Rimaggalatung (Prima) Sengkang}

STKIP Prima Sengkang didirikan pada tanggal 14 Mei 1980 dengan dilatarbelakangi beberapa faktor, antara lain: 1) tugas belajar bagi guruguru TK, SD, SLTP, dan SLTA Negeri ke ibukota propinsi ditiadakan, 2) biaya kuliah di ibukota propinsi relatif tinggi, 3) keengganan sebagian orang tua untuk menyekolahkan anak-anaknya di kota-kota besar, dan 4) Masih banyaknya PNS di Kabupaten Wajo belum mendapat kesempatan tugas belajar.

Nama Puang Rimaggalatung yang di berikan pada nama lembaga perguruan tinggi ini diambil dari nama Arung Matoa (Raja) yang keempat. Raja ini memerintah kerajaan Wajo selama 30 tahun (1491-1521) dan berhasil mengantar masyarakat Wajo pada masa keemasan dengan berpegang pada empat prinsip dalam kepemimpinannya, yaitu jujur, pintar, berani, dan kaya batin.

STKIP Puang Rimaggalatung membina dua program studi, yaitu program studi Administrasi Pendidikan dan program studi Biologi dengan jenjang pendidikan $\mathrm{S} 1$. Kedua program studi itu dibina oleh 50 orang dosen tetap dan 22 orang dosen tidak tetap. Satu di antara dosen tetap itu dalam status sebagai PNS dari Kopertis yang dipekerjakan. Jumlah tenaga administrasi sebanyak 10 orang yang bertugas sebagai pelaksanana administrasi, pustakawan, laboran, dan penjaga kampus.

\section{Sekolah Tinggi Keguruan dan Ilmu Pendidikan (STKIP) dan Sekolah Tinggi Ilmu Ekonomi (STIE) Yayasan Pendidikan Turatea Indonesia (YAPTI) Jeneponto}

Yayasan Pendidikan Turatea Indonesia (YAPTI) berdiri pada tahun 1986 dan pada mulanya hanya mengelola sebuah perguruan tinggi, yaitu Sekolah Tinggi Keguruan dan Ilmu Pendidikan (STKIP). Yayasan ini mendirikan perguruan tinggi di Jeneponto dilatarbelakangi oleh kondisi masyarakat yang tidak mampu menyekolahkan anaknya pada perguruan tinggi negeri atau swasta di ibukota propinsi. Perjalanan perguruan tinggi yang dikelola oleh yayasan ini mengalami pasang surut. Pada tahun 1990, 
STKIP yang baru empat tahun beroperasi dibekukan, dan dua tahun kemudian pada tahun 1992 YAPTI di SK-kan untuk mengelola kembali STKIP, dengan jurusan Program Pendidikan Dunia Usaha, program studi Pendidikan Koperasi dan hingga sekarang telah menghasilkan 66 alumnus. Pada tahun 1993, Kopertis Wilayah IX Sulawesi, menerbitkan lagi SK baru bagi YAPTI untuk mendirikan dua PTS, yaitu STIP DAN STIE.

STIE YAPTI membuka dua konsentrasi bidang studi, yaitu bidang studi ilinu ekonomi dan studi pembangunan. Sementara STKIP membuka tiga jurusan, yaitu jurusan Bahasa dan Sastra Indonesia, Matematika, dan Jurusan Biologi. Menurut data tahun 2002, jumlah mahasiswa kedua perguruan tinggi ini sebanyak 418 orang, terdiri atas 265 orang mahasiswa STIE dan 152 orang mahasiswa STKIP. Pada umumnya mahasiswa tersebut adalah adalah PNS yang bertugas sebagai pegawai dan guru, sedangkan mahasiswa murni yang belum mempunyai pekerjaan jumlahnya sedikit.

\section{B. Pendidikan dan Kegiatan Keagamaan di Kampus}

Berdasarkan peraturan pemerintah, mata kuliah Pendidikan Agama wajib diikuti oleh seluruh mahasiswa. Oleh karena itu, semua mahasiswa pada perguruan tinggi yang diteliti mengikuti mata kuliah itu sebagai mata kuliah umum dalam satu semester dengan 2 SKS. Penyelenggaraan Pendidikan Agama Islam dilaksanakan atas dasar kurikulum yang disusun oleh masing-masing perguruan tinggi dengan mengacu kepada kurikulum yang berlaku secara nasional.

Penyelenggaraan Pendidikan Agama Islam di perguruan tinggi mempunyai otonomi yang luas, baik dalam hal pengembangan materi maupun rekruitmen tenaga pengajar. Atas otonomi tersebut, masing-masing dosen Pendidikan Agama Islam mempunyai kebebasan untuk mengembangkannya sesuai dengan visi dan misi pendidikan agama itu dengan tetap mengacu pada kurikulum nasional. Pada STKIP DDI Polmas, Pendidikan Agama Islam dibagi dua bagian, Pendidikan Agama Islam I dan Pendidikan Agama Islam II. Pendidikan Agama Islam I diberikan dalam 2 SKS berdasarkan kurikulum nasional, sedangkan Pendidikan Agama Islam II diberikan dalam 3 SKS dengan materi ke-DDI-an dan Asy'ariyah. Dengan adanya otonomi itu pula, setiap perguruan tinggi mempunyai ciri dan corak masing-masing dalam proses penyelenggaraan pendidikan agama, baik materi yang diberikan maupun alokasi waktunya.

Walaupun pelaksanaan pendidikan agama Islam diberikan otonomi kepada masing-masing perguruan tinggi, namun metode pengajaran yang 
digunakan dikeluhkan oleh sebagian mahasiswa, karena materi dan metode kurang mengena. Materinya dianggap membosankan, karena hanya membicarakan hal-hal yang bersifat ritual dan akidah, hal-hal yang aktual kurang mendapat tempat. Selain itu, metode pembelajaran masih menggunakan metode konvensional, seperti ceramah dan dialog, sehingga orientasi kuliah lebih mengarah kepada dakwah. Penilaian tersebut mewakili mahasiswa yang pengetahuan agamanya di atas rata-rata, seperti dari pesantren atau mahasiswa yang menginginkan pengetahuan agama yang praktis. Oleh karena itu, mereka menginginkan materi agama memiliki bobot ilmiah, lebih problematis, ada relevansinya dengan kekinian dan ada kaitannya dengan masing-masing fakultas dan jurusan.

Kegiatan dan aktivitas keagamaan yang dilakukan mahasiswa di beberapa kampus yang diteliti tampak beragam, didukung dan direspon oleh semua pihak, otoritas kampus, organisasi intra dan ekstra, dan kelompokkelompok keagamaan. Di antara kegiatan dan aktivitas keagamaan itu adalah: 1) pengamalan ajaran agama dalam bentuk ibadah, 2) peringatan hari-hari besar Islam, 3) pelatihan dan pengkaderan, 4) seminar, pengkajian dan bedah buku.

Pada umumnya kegiatan dan aktivitas keagamaan mahasiswa dipusatkan di masjid dan mushalah dalam kampus yang tersedia sesuai dengan kondisi perguruan tinggi itu. Hampir semua perguruan tinggi yang diteliti memiliki tempat ibadah berupa masjid atau musala. Di Unhas, kegiatan keagamaan dilaksanakan pada 11 mesjid dan musala, dan dari jumlah tersebut hanya dua yang dibangun secara representatif sebagai mesjid, yaitu Masjid Al-Ikhtiar sebagai mesjid yang terbesar dan Mesjid Ulil Albab di Fakultas Pertanian dan Kehutanan. Sedangkan yang lainnya berbentuk mushala yang mengambil salah satu ruangan pada bangunan fakultas, atau memanfaaatkan bekas kantin yang tidak terpakai lagi, kemudian disulap menjadi masjid, seperti Masjid Khairun Nisa dan Masjid Darul Ilmi yang keduanya berada di sekitar asrama Ramsis.

Aktivitas keagamaan di kalangan mahasiswa tampak sangat marak, utamanya menjelang pelaksanaan shalat lima waktu, mereka melaksanakan secara berjamaah di mesjid dan musala yang ada. Di beberapa musala, sering shalat berjamaah terpaksa bergantian dilakukan karena ruangannya tidak mampu menampung untuk shalat berjamaah sekaligus. Selain shalat berjamaah, sering pula dilakukan ceramah dan pengkajian agama dan bertindak sebagai nara sumber dosen dan mahasiswa senior dalam kalangan kampus sendiri, serta dari luar, misalnya Wahdah, Tablig, dan STIBA. 
Fenomena lain kehidupan keagamaan yang disaksikan setiap hari di kampus adalah mahasiswi yang berjilbab, bahkan ada yang memakai cadar dengan menutup mukanya, dengan berbagai ragam warna dari warna gelap sampai warna terang, memakai sarung tangan dan kaos kaki. Di kalangan mahasiswa, sebagian diantaranya terlihat memakai baju koko, memelihara jenggot, memakai celana panjang di atas mata kaki, penampilannya mengesankan kesederhanaan, tawadhu dan kesalehan.

Peringatan hari-hari besar Islam dilakukan secara rutin setiap tahun, baik secara bersama oleh seluruh komponen dalam kampus, maupun dilakukan oleh masing-masing organisasi intra atau ekstra, seperti peringatan tahun baru Islam, maulid, dan isra miraj. Peringatan hari-hari besar Islam dilakukan berbagai kegiatan, antara lain upacara serimonial yang dirangkaikan dengan ceramah agama, seminar, dan berbagai perlombaan.

\section{Kelompok-Kelompok Keagamaan Mahasiswa}

Kelompok-kelompok keagamaan mahasiswa hanya terdapat pada tiga dari enam perguruan tingi yang diteliti, yaitu Universitas Hasanuddin Makassar, Universitas Negeri Makassar, dan Sekolah Tinggi Keguruan dan Ilmu Pendidikan Cokroaminoto di Palopo. Hal itu disebabkan karena pada umumnya mahasiswa ketiga perguruan tinggi tersebut adalah mahasiswa murni yang merupakan alumni Sekolah Lanjutan Tingkat Atas yang belum mempunyai pekerjaan tetap, sehingga waktu di luar kegiatan belajar dapat dimanfaatkan untuk berbagai aktivitas. Berbeda halnya dengan tiga perguruan tinggi lainnya, di mana pada umumnya mahasiswanya bekerja sebagai pegawai negeri, baik guru maupun pegawai.

Kelompok-kelompok keagamaan mahasiswa dapat diklasifikasi pada dua macam, yaitu kelompok keagamaan yang mendapat legitimasi dari pejabat otoritas kampus dan kelompok keagamaan yang tidak mendapat legitimasi. Kelompok keagamaan yang mendapat legitimasi otoritas kampus adalah:

\section{Lembaga Dakwah Kampus Mahasiswa Pencinta Mushala (LDK- MPM) Unhas.}

Lembaga Dakwah Kampus Mahasiswa Pencinta Mushala didirikan pada tanggal 15 Desember 1988 M. bertepatan dengan 5 jumadil awal 1409 H. berasaskan Al-Qur'an dan Assunnah sesuai pemahaman ulama salaf. Lembaga ini merupakan satu-satunya lembaga keagamaan di tingkat universitas yang mendapat legitimasi dari Rektor Unhas, karena struktur pengurusannya di SK-kan oleh Pembantu Rektor III. Struktur pengurusnya 
terdiri dari pelindung, pembina, majelis syura, dan pengurus harian. Pelindung adalah Rektor Unhas, pembina sebanyak 16 orang dari kalangan dosen Unhas yang diketuai oleh Pembantu Raktor III, majelis syura sebanyak 5 orang dari kalangan mahasiswa senior. Pengurus harian terdiri dari Ketua Umum, dibantu oleh 2 orang wakil ketua, satu orang sekertaris umum dibantu 2 orang wakil Sekertaris, Bendahara dibantu oleh 2 orang wakil. Struktur kepengurusan ini dilengkapi dengan 4 biro dan 4 departemen. Biro yang dimaksud adalah biro rumah tangga mesjid, adik asuh, dan biro dana dan usaha. Keempat departemen adalah departemen penelitian dan pengembangan, kaderisasi dan mentoring, hubungan masyarakat, kesekretariatan dan logistik.

Setiap biro dan departemen terdiri dari satu orang koordinator dan satu orang sekretaris serta dilengkapi beberapa orang anggota. Dalam setiap biro dan departemen itu antara pengurus laki-laki dan pengurus perempuan (mahasiswi) dipisahkan, artinya pengurus laki-laki yang disebut pengurus ikhwan khusus mengurusi mahasiswa dalam menjalankan tugasnya, sedangkan pengurus perempuan yang disebut dengan pengurus akhwat khusus mengurusi mahasiswi dalam menjalankan tugasnya.

Tujuan pembentukan lembaga keagamaan ini adalah: 1) untuk menghimpun dan mengembangkan semua potensi yang dimiliki oleh mahasiswa Islam unutk ikut serta mengembangkan kontribusi positif demi kemaslahatan dan kejayaan umat Islam. 2) senantiasa berusaha menjadi lembaga dakwah kampus yang menegakkan kebaikan dan mencegah kemungkaran yang didasari oleh aqidah dan Ukhuwah Islamiyah.

Tujuan tersebut sesuai dengan visi dan misi lembaga, yaitu menegakkan dan membina akidah yang saleh, mempererat ukhuwah dan menghidupkan syiar Islam serta mewujudkan Tri Darma perguruan tinggi yang dilandasi dengan keimanan dan ketaqwaan guna merealisasikan tata kehidupan masyarakat yang diridhohi oleh Allah swt.

Dalam menindak lanjuti visi misi tersebut beberapa usaha yang dilakukan lembaga ini, antara lain: 1) pengkaderan melalui kegiatan studi Islam intensif, 2) kajian agama Islam yang dilaksanakan secara rutin pada minggu kedua setiap bulan, 3) penerbitan bulletin setiap hari Jum'at dan dibagikan kepada jamaah secara gratis.

Usaha-usaha tersebut dilakukan untuk memberikan pengetahuan agama Islam kepada mahasiswa agar dapat membentengi diri dari fahamfaham sekuler yang berkembang sekarang ini. 
mereka melakukan proses kaderisasi melalui kegiatan training yang diberi nama Studi Islam Intensif I dan Studi Islam Intensif II. Materi dan narasumber yang mereka rekrut dalam studi ini disesuaikan dengan kebutuhan LKIMB. Pasca training para anggota LKIMB diperkenalkan dengan pemikiran-pemikiran Islam kontemporer yang sesuai dengan visi mereka serta melakukan kritik terhadap nalar Islam yang dianggap tidak sesuai dengan visinya melalui kegiatan bedah buku. Kesemuanya ini mengarah pada meningkatkan kapasitas intelektual dan nalar Islam serta penghayatan keagamaan anggota LKIMB.

Sedang orientasi eksternal diarahkan pada upaya mempengaruhi perkembangan wacana keagamaan mutakhir dalam rangka membangun wacana keagamaan tandingan yang dianggap bertentangan dengan visi LKIMB. Proses membangun wacana tandingan ini dilakukan mulai dari kajian intensif yang hasilnya disosialisasi dalam bentuk majalah atau semacamnya, kemudian melakukan perayataan sikap atau aksi lapangan kalau memang diperlukan sebagai hasil refleksi keagamaan dan kajian. Tema kajian yang dianggap sangat urgen dan signifikan dengan visi LKIMB dilakukan seminar.

Kepengurusan LKIMB terdiri atas Pelindung, Pembimbing, Majelis Syuro Organisasi (MSO) dan Pengurus Harian. Pelindung Rektor Universitas Negeri Makassar, Pembimbing 3 orang dosen UNM, Majelis Syuro Organisasi (MSO) 10 orang alumni dan mahasiswa senior. Pengurus Harian terdiri atas Ketua Umum, Sekretaris Umum, Bendahara Umum, dan Wakil Bendahara. Struktur kepengurusan ini dilengkapi dengan 3 bidang dan satu lembaga khusus. Ketiga bidang adalah Bidang Pelatihan dan Pembinaan Kader (BPPK), Bidang Pengembangan Wacana (BPW), dan Bidang Humas dan Pengembangan Organisasi (BHPO). Lembaga khusus adalah Lembaga Khusus Keputrian LKIMB UNM. Lembaga khusus ini memiliki pengurus terdiri dari Ketua Umum, Sekretaris, Bendahara, dan dua bidang, yaitu bidang intern dan bidang ekstern.

Dalam melakukan kajian dan diskusi, mereka mengambil narasumber dari kalangan mereka sendiri terutama mahasiswa lepasan kader LKIMB. Narasumber lain yang biasa mereka hubungi adalah kalangan mahasiswa lepasan kader Himpunan Mahasiswa Islam (HMI) serta kalangan dosen yang dianggap memiliki perhatian terhadap kajian Islam. Sedang narasumber utama mereka adalah Ustad Hasan Abu Ammar dari Iran. 
Penggunaan narasumber seperti diatas tidak terlepas dari kebijakan organisasi, penggunaan mahasiswa lepasan kader LKIMB sendiri dilakukan dalam rangka menjaga proses regenerasi kader, berbeda dengan penggunaan narasumber yang berasal dari lepasan kader HMI dilakukan dalam rangka menjaga hubungan kemitraan antar kedua organisasi. Penggunaan nara sumber dari kalangan dosen yang memiliki perhatian terhadap Islam dimaksndkan untuk mencari relasi dengan dosen yang dianggap bisa menjadi pengayom organisasi. Sedangkan penggunaan Ustads Hasan Abu Ammar dari Iran sebagai nara sumber dimaksudkan untuk menjaga dan memelihara ideologi gerakan serta wacana keislaman yang terbangun dalam tubuh LKIMB.

\section{Lembaga Dakwah Kampus Mahasiswa Pencinta Mushalla (LDK- MPM) STKIP Cokroaminoto}

Lembaga Dakwah Kampus Mahasiswa Pencinta Mushalla STKIP Cokroaminoto didirikan pada akhir tahun 2003 dan dilatarbelakangi oleh beberapa alasan: 1) mayoritas mahasiswa beragama Islam, 2) salah satu visi, misi dan tujuan perguruan tinggi ini adalah menghasilkan lulusan yang islami, membina suasana kehidupan akademik yang islami, dan membentuk sarjana yang cakap dan menguasai ilmu, keterampilan, sikap dengan tetap berlandaskan pada ketakwaan terhadap Allah swt, 3) pola dasar pembangunan Kota Palopo 2003-2007 dengan memcanangkan Kota Palopo sebagai Kota Tujuh Dimensi, dan sebagai dimensi pertama adalah Kota Religi, 4) pimpinan perguruan tinggi ini memberikan peluang yang besar kepada mahasiswa untuk menyelenggarakan berbagai kegiatan keagamaan, dan 5) adanya rencana mahasiswa non muslim untuk mengadakan kegiatan keagamaan di kampus.

Seperti halnya LDK di Unhas, lembaga ini pula mendapat legitimasi dari Ketua STKIP, dengan struktur organisasinya di tetapkan berdasarkan SK Ketua STKIP tanggal 4 Nopember 2003. Struktur pengurusnya terdiri dari pelindung, pembina, dan pengurus. Pelindung adalah Ketua STKIP, pembina Ketua Senat mahasiswa STKIP, dan pengurus terdiri dari Ketua Umum, dibantu oleh seorang wakil ketua, satu orang sekretaris, dan satu orang bendahara. Struktur kepengurusan ini dilengkapi dengan 3 bidang, yaitu bidang kaderisasi, pendidikan dan pelatihan, dan bidang humas.

Kegiatan lembaga ini telah dirumuskan dalam program kerja, yaitu: 1) pembenahan administrasi, 2) pengumpulan dana organisasi melalui pembuatan kalender, pengumpulan dana awal, bulanan, dan kotak amal, 
3) taklim/tarbiyah, 4) buka puasa bersama, 5) daurah islamiyah, 6) majalah dinding, 7) bedah buku, 8) latihan jurnalistik, 9) bakti sosial, dan 10) kunjungan ke panti asuhan.

Selain kelompok-kelompok keagamaan yang secara resmi diakui oleh otoritas kampus masih ada beberapa kelompok keagamaan lainnya yang berkembang dan berpengaruh dalam kampus yang tidak mendapat legitimasi kampus, diantaranya:

\section{Uswah (Ukhuwah Mahasiswa Muslim) Universitas Hasanuddin}

Kelompok keagamaan ini dibentuk pada tahun 2001 diawali dari semangat beberapa orang mahasiswa dari beberapa fakultas dan sekaligus sebagai pemrakarsa terbentuknya lembaga ini. Beberapa fakultas yang dimaksud adalah Ekonomi, Kedokteran, Fisipol, MIPA, Kesehatan Masyarakat, Kehutanan, dan Teknik. Pembentukan lembaga ini dilatarbelakangi oleh beberapa kenyataan adanya sebagian masyarakat Islam memahami Islam hanya dari segi ritualnya saja dengan melupakan aspek sosialnya, sehingga dengan melalui kelompok kajian ini diharapkan dapat memberikan pencerahan kepada umat Islam untuk memahami Islam secara sempurna (kaffah). Hal ini sesuai dengan visinya yaitu: menghidupkan syiar keislaman di kalangan mahasiswa khususnya dan umat Islam pada umumnya sebagai wadah mengkaji ajaran Islam.

Aktivitas kelompok ini dipusatkan mesjid Darul Ilmi yang pada mulanya merupakan kantin 01 Unhas di asrama Ramsis yang tidak dimanfaatkan lagi, kemudian dijadikan oleh mahasiswa yang tergabung dalam kelompok kajian ini untuk dijadikan mesjid, gedung ini berlantai dua.

Lembaga ini mempunyai struktur kepengurusan di tingkat universitas dan tingkat fakultas. Pengurus di tingkat universitas terdiri dari seorang ketua, wakil ketua, sekretaris dan departemen pengkaderan, kajian sirategis. Pengurus pada tiap-tiap fakultas akan mengkaji setiap permasalahan yang muncul sesuai dengan fakultasnya masing-masing. Sebagai contoh adalah pengurus di Fakultas Kedokteran mengkaji suatu penyakit dari si si ajaran Islam, ketika wabah penyakit SARS muncul beberapa waktu yang lain, pengurus di Fisipol mengkaji permasalahan politik dari sudut pandang Islam. Fakultas Ekonomi mengkaji ekonomi dari sisi Islam. Beberapa pandangannya tentang masalah sosial ekonomi di antaranya krisis ekonomi yang telah melanda beberapa negara di dunia termasuk Indonesia. Untuk mengatasinya. kita harus kembali padapenggunaan mata uang Dinar dan Dirham. Kemudian 
aset negara mutlak harus diurus oleh negara bukan swasta sebagaimana yang telah berlaku selama ini.

Sistem bunga bank tidak sesuai dengan ajaran Islam, oleh karena itu kita harus kembali pada sistem Ekonomi Islam yaitu Bank Syariah. Lembaga ini identik dengan Hizbut Tahrir yang mengarah pada masalah politik. Beberapa pandangannya tentang politik antara lain: tentang suksesi kepemimpinan nasional. Menurut kelompok ini tidak melihat pada figur seorang pemimpin, tetapi lebih pada kriterianya, yakni yang dapat memperjuangkan umat Islam dan tidak berlaku represif terhadap kelompok Islam.

\section{Partai Keadilan}

Ide pembentukan lembaga ini dimulai pada tahun 1990 dengan menjadikan Masjid Khairun Nisa sebagai markasnya, bekas kantin Unhas di Asrama Ramsis. Tujuan pembentukan lembaga ini adalah untuk menumbuhkan semangat keislaman pada diri mahasiswa khususnya dan pada umat muslim pada umumnya. Untuk merealisasikan tujuan tersebut lembaga ini mengaktifkan Lembaga Dakwah Islam dalam bentuk pengajian di kalangan mahasiswa dan masyarakat kampus. Ada dua jenis pengajian yang diaktifkan yaitu dalam bentuk pengajian dasar yang diistilahkan Studi Islam Dasar Intensif (SIDI) dan pengajian lanjutan yang diistilahkan dengan Studi Islam Lanjutan Intensif (SILI). Kegiatan pengajian dipusatkan di Masjid Khairun Nisa yang diikuti oleh mahasiswa dan masyarakat umum yang ada di sekitar kampus.

Selain kegiatan pengajian yang diadakan di mesjid, ada pengajian yang dilaksanakan di rumah dan asrama mahasiswa di dalam kampus. Anggota yang berada di asrama putra dan putri kegiatannya tidak disatukan tapi diadakan di asrama masing-masing. Untuk asrama putri diistilahkan dengan pegajian RT, sedangkan untuk pengajian putra diistilahkan dengan pengajian Blok.

Untuk menghidupkan dan menggairahkan semangat keislaman di kalangan mahasiswa dan masyarakat di Indonesia, perlu ditegakkan syariat Islam. Oleh karena itu sistem pemerintahan di Indonesia harus dirubah, dengan menghidupkan kembali sistem kekhalifaan sebagai yang berlaku di zaman Nabi Muhammad saw. 


\section{AIWahdah}

Tidak diketahui dengan pasti kapan kelompok ini masuk ke dalam kampus Unhas. Pemrakarsa kelompok ini adalah beberapa orang mahasiswa yang mengikuti pengajian yang diadakan di mesjid Al Wahdah Jalan Abdullah Dg. Sirua Makassar yang merupakan pusat kegiatan kelompok. Mahasiswa yang aktif mengikuti pengajian kelompok tersebut menginformasikan dan mengajak temannya yang lain untuk mengikuti kegiatan pengajian.

Walaupun pengikut kelompok ini dalam kampus cukup banyak namun tidak membentuk suatu organisasi yang mempunyai struktur kepengurusan. Pengaruh kelompok ini sangat besar di kalangan mahasiswa, karena selain sebagian besar mereka sebagai pengurus Lembaga Dakwah Kampus Mahasiswa Pencinta Mushalla di Unhas, juga nara sumber dari pengajian mahasiswa di kampus berasal dari Al-Wahdah.

\section{Kesatuan Aksi Mahsiswa Muslim Indonesia (KAMMI) di UNM}

KAMMI adalah sebuah organisasi kemahasiswaan yang bergerak di bidang perkaderan yang sarat dengan nuansa keimanan dan ketakwaan kepada Allah swt., bidang sosial kemasyarakatan yang sarat dengan aksi sosial berupa pelayanan kepada masyarakat, bidang politik yang berperan sebagai pengontrol dan berusaha meluaskan proses pemerintahan dengan cara yang baik dan bil hikmah. Kegiatan organisasi digambarkan secara ringkas dalam sebuah motto: "ibadah taat, aksi kuat, prestasi hebat". KAMMI dideklarasikan di Universitas Muhammadiyah Malang pada tanggal 29 Maret 1998 ditandai dengan pembacaan Deklarasi Malang. Organisasi ini terus berkembang dan kini mempunyai berbagai cabang diseluruh Indonesia dan luar negeri.

Organisasi ini merupakan basis pembentukan kepemimpinan masa depan untuk mewujudkan terbentuknya masyarakat Islam. Untuk itu, dilakukan berbagai kegiatan, antara lain: 1) seminar, 2) kaderisasi melalui tiga tahap daurah marhalah, 3) pembentukan sekolah politik, 4) kajian rutin, 6) pembinaan kader secara berkelompok, 7) bedah buku, dan 8) menyikapi perkembangan sosial politik di Indonesia dengan melakukan aksi demonstrasi.

Kepengurusan lembaga ini terdiri atas tingkat pusat, wilayah, daerah, dan pengurus tingkat perguruan tinggi. Narasumber berasal dari kalangan KAMMI sendiri yang sudah melalui jenjang pengkaderan Daurah Marhalah I (DM I), Daurah Marhalah II (DM II), dan Daurah Marhalah III (DM III), dari proses inilah pengurus KAMMI mengangkat murabbi sebagai narasumber dan pembina pada setiap kegiatannya. 
Selain kelompok-kelompok keagamaan yang telah diuraikan di atas masih ada beberapa kelompok lainnya yang berkembang dalam kampus walaupun pengikutnya tidak terlalu banyak, diantaranya: Ikatan Jamaah Ahlul Bait Indonesia (Ijabi). Kelompok ini pemikirannya banyak dipengaruhi oleh ajaran Syiah. Ada juga kelompok yang menamakan diri Forum Studi Intensif Dinul Islam (FOSIDI), kelompok ini berada di bawah naungan dan binaan Al Wahdah.

Munculnya kelompok-kelompok keagamaan di beberapa perguruan tinggi tidak bisa dipisahkan dari faktor internal kampus sendiri, disamping faktor eksternal umat Islam, baik di Indonesia maupun di negara lain. Di antara faktor-faktor tersebut adalah :

1. Semakin banyaknya alumni Timur Tengah yang pemikirannya sejalan dengan ideologi Ikhwanul Muslimin berkenalan dengan masyarakat kampus.

2. Banyaknya penerbitan buku-buku terjemahan karya ulama pembaharu pemikiran Islam dan tokoh-tokoh gerakan dan organisasi Islam yang berpengaruh, misalnya ulama Syiah, dan pemikir Ikhwanul Muslimin.

3. Banyak mahasiswa yang berasal dari keluarga muslim, yang secara kultural telah mengenal Islam, mereka pada umumnya memiliki hubungan emosional dengan kelompok keagamaan yang secara aspiratif memperjuangkan ideologi agama. Tidak sedikit diantara mereka yang telah masuk organisasi yang menjadikan Islam sebagai ideologi mereka. Karenanya ketika mereka ketika masuk kampus, mereka menemukan kelompok yang memiliki pandangan keagamaan yang sama.

4. Adanya depolitisasi kampus pada masa Orde Baru melalui NKK dan BKK, menjadikan mahasiswa kehilangan romantisme yang selama ini melekat pada diri mereka seperti kepeloporan, kejuangan, demokrasi, kontrol sosial dan sebagainya. Kebuntuan penyaluran potensi politik mereka mengkondisikan munculnya gerakan keagamaan sebagai salah satu penyalur aspirasi.

5. Semangat solidaritas Islam yang senantiasa ditanamkan kepada setiap anggota jamaah sehingga mereka menjadi bagian dari muslim lainnya. Itulah sebabnya ketika terjadi berbagai kasus pada masyarakat Islam di negara-negara lain, kegiatan kelompok keagamaan itu semakin intensif.

6. Derasnya arus budaya luar dalam era informasi dan globalisasi dianggap sebagai tantangan yang merusak keyakinan dan moral umat Islam. Umat Islam dinilai banyak yang telah menanggalkan agama mereka, dan mengambil budaya barat yang kafir dan sekuler sebagai cara 
hidupnya. Demikian pula berbagai disiplin ilmu yang diajarkan di sekolahsekolah mulai dari tingkat dasar sampai pada tingkat perguruan tinggi dianggap sekuler dan merusak pemikiran umat.

7. Terjadinya kelesuan organisasi ekstra, seprti HMI, PMII, dan IMM dan sudah tidak menjadi alternatif utama bagi mahasiswa dalam melakukan kegiatan ekstra. Kelesuan organisasi ekstra dikarenakan mahasiswa melihat organisasi ekstra hanya menjadi organisasi yang paragmatis, terjebak dalam rutinitas, mencari kedudukan, sebagai sarana politik, dan tidak lagi mewakili aspirasi dari bawah.

\section{Pandangan Kelompok-Kelompok Keagamaan Terhadap Berbagai Aspek Kehidupan}

Pandangan kelompok-kelompok keagamaan yang muncul dan melakukan aktivitas di beberapa perguruan tinggi berkaitan dengan latar belakang keberadaan kelompok-kelompok keagamaan tersebut. Oleh karena itu pandangan kelompok-kelompok tersebut menyangkut berbagai aspek ajaran Islam dan aspek kehidupan manusia, dan pandangan itu disampaikan dan didiskusikan dalam berbagai pertemuan, pengajian, seminar, bedah buku, baik dilakukan secara perorangan maupun kelompok.

Tema kajian yang selama ini dibahas dalam berbagai kelompok keagamaan yang diinventarisir dalam penelitian ini, antara lain:

\section{Aspek keyakinan dalam Islam}

Aspek keyakinan merupakan aspek yang paling dasar dalam Islam, oleh karena itu aspek ini banyak dibahas dalam berbagai kegiatan kelompok. Aspek keyakinan yang dikaji, antara lain:

a. Keesaan Allah (tauhid), pengertian, dan macam-macam tauhid (tauhid uluhiyah, rububiyah, dan asma wassifat, serta tauhid di tengah berbagai pluralisme ideologi dunia).

b. Pengertian jabar dan ikhtiar, serta tokoh-tokohnya dan kritik terhadap keduanya.

c. Pengertian qadha dan qadar, hubungan keduanya dan kebebasan manusia.

d. Keadilan ilahi yang memuat pengertian keadilan ilahi, argumentasi keadilan ilahi, dan beberapa kritikan terhadap keadilan Ilahi

e. Mengenal Tuhan yang mengkaji tentang pembagian pengetahuan khusuli dan khuduri serta pengetahuan fitri 
f. Pembuktian keberadaan Tuhan yang memuat dalil aqli (filosofis), dalil naqli, dalil fltri, dan dalil siddiqin

g. Sifat-sifat Tuhan yang membahas masalah pembagian sifat-sifat Tuhan, sifat dzati, dan sifat fi'li.

\section{Aspek ibadah dalam Islam}

Kajian ibadah yang sering disampaikan dalam pengajian dan diskusi adalah perlunya ibadah dilakukan secara ketat sesuai dengan yang dipraktekkan Rasulullah saw, antara lain pelaksanaan shalat di awal waktu, pelaksanaan shalat dengan berjamaah, anjuran pelaksanaan salat-salat sunat, misalnya salat rawatib, tahajjud, salat dhuha dan sebagainya, berzikir dan berdoa, memperbanyak membaca Alquran, dan mendengarkan bacaan Alquran.

Berdasarkan kajian tentang ibadah itu, sebagian mahasiswa membiasakan diri melaksanakan salat secara berjamaah di awal waktu dengan aturan-aturan yang ketat yang menurut mereka sebagaimana yang dicontohkan oleh Nabi Muhammad saw. kepada sahabatnya. Oleh karena itu, aktivitas keagamaan di kalangan mahasiswa tampak sangat marak, utamanya menjelang pelaksanaan shalat lima waktu, dan mereka melaksanakan secara berjamaah di mesjid dan musala yang ada. Bila tiba waktu shalat, mahasiswa yang tidak kuliah segera menuju mushalla di fakultasnya masing-masing, mengambil air wudhu, shalat sunnat rawatib, dzikir untuk menunggu waktu shalat berjamaah. Pada waktu dhiiha, kadangkadang terlihat mahasiswa shalat dhuha, dzikir dan i'tikaf atau membaca Al-Qur'an di musala.

\section{Aspek ilmu pengetahuan dan teknologi dalam Islam}

Berkaitan dengan aspek ilmu pengetahuan dan teknologi dalam Islam yang disampaikan dalam berbagai kajian cukup beragam, di antaranya:

a. Islam dan problematika sains kontemporer yang membahas tentang kelahiran sains dan perkembangannya, perkembangan sains abad ke20 dan perkembangan selanjutnya, serta pandangan Islam mengenai sains.

b. Islam dan kritik atas kehidupan modern yang memuat tentang studi kritis atas modernisme, posisi umat Islam dalam kehidupan modern, dan peran umat Islam dalam kehidupan modern.

c. Sebab-sebab penyelewengan dalam agama yang memuat sebab psikologis, sosiologis, dan sebab filosofis. 
d. Alam pemikiran materialisme dan penolakannya yang memuat tentang dasar teori materialisme dan kritik terhadap dasar materialisme.

e. Fenomena keberagamaan di Indonesia yang memuat sejarah agamaagama, perkembangan agama-agama di Indonesia, dan fenomena keberagamaan di Indonesia.

f. Pengantar Tasawuf yang membahas masalah defenisi tasawuf, sejarah perkembangan Tasawuf, dan tasawuf dalam wacana pemikiran kontemporer.

g. Studi mazhab pemikiran Islam yang membahas masalah defenisi mazhab pemikiran Islam, pembagian mazhab pemikiran Islam, dan konstribusi pemikiran Islam dalam perkembangan peradaban dunia.

h. Islam dan perkembangan budaya kontemporer yang membahas masalah pengertian budaya Islam, masyarakat dan budaya, kulturasi Islam dalam masyarakat, dan studi kritis budaya kontemporer.

\section{Aspek sosial, ekonomi, dan politik dalam Islam}

Aspek sosial, ekonomi, dan politik yang dikaji sangat beragam, di antaranya:

a. Islam di tengah pluralitas ideologi dunia yang menuat pengertian ideologi, ragam ideologi dunia, dan Islam sebagai ideologi.

b. Hijab, akhlak, dan perilaku muslim yang memuat pengertian hijab, prinsipprinsip dasar akhlak dan perilaku muslim, dan prinsip pergaulan dan interaksi sejarah peradaban Islam.

c. Konsepsi akhlak dan pergaulan muslim yang memuat konsep dasardasar akhlak dan konsep dasar-dasar pergaulan Islam.

d. Aktualisasi jihad yang memuat tentang pengertian jihad dan mujahid, makna jihad dan macam-macam jihad (lahir dan batin), syarat-syarat jihad dan mujahid, etika-etika jihad, dan syarat-syarat diterimanya jihad dijalan Allah.

e. Keharusan berdakwah yang memuat tentang pengertian dakwah, macam-macam dakwah, urgensi penyampaian dakwah, dan teknikteknik berdakwah.

f. Peran organisasi dalam perjuangan umat, organisasi dalam Islam, dan organisasi sebagai alat perjuangan.

g. Posisi Islam di tengah ideologi dunia yang bermuatan peta konstruksi ideologi-ideologi dunia, penjelasan Islam sebagai ideologi, dan posisi Islam sebagai ideologi di tengah ideologi-ideologi dunia. 
h. Konsepsi diri manusia sebagai khalifah dalam konstalasi keumatan yang membahas tentang pengertian khalifah, tugas-tugas manusia sebagai khalifah, problematika konstalasi keumatan, dan kekhalifaan dalam konstalasi keumatan.

i. Studi kritis sistem pendidikan kontemporer yang membahas tentang pengertian sistem pendidikan, konsep-konsep pendidikan kontemporer, problematika pendidikan kontemporer, dan studi tentang birokrasi sekolah.

j. Proyeksi peta politik Indonesia dan global yang membahas defenisi ilmu politik, peta politik dunia, peta politik Indonesia, serta poroyeksi peta politik Indonesia dan global.

Pandangan kelompok-kelompok keagamaan mahasiswa yang menyangkut berbagai aspek ajaran Islam dan aspek kehidupan manusia tersebut mengacu kepada pandangan ulama-ulama yang mempunyai pengaruh yang besar di dunia Islam, seperti Hasan al-Banna, Nurcholis Madjid, Ali Syariati, Murtadha Muthahhari, Fazlurrahman, Jalaluddin Rahmat, Hautan Ahmad Jais, Abu Al-Fiary, dan Sayyid Qutub.

\section{KESIMPULAN}

Kehidupan keagamaan mahasiswa di berbagai perguruan tinggi semakin semarak dari tahun ke tahun dengan adanya respons dari semua komponen kampus, tersedianya sarana dan prasarana ibadah, dan munculnya berbagai kelompok keagamaan.

Munculnya kelompok-kelompok keagamaan di beberapa perguruan tinggi tidaklah terjadi secara tiba-tiba, tetapi melalui proses yang panjang, dan munculnya kelompok-kelompok tersebut tidak bisa dipisahkan dari faktor internal kampus sendiri, disamping faktor eksternal umat Islam, baik di Indonesia maupun di negara lain.

Kegiatan dan aktivitas kelompok-kelompok keagamaan itu berdasar pada dua orientasi, yaitu internal dan eksternal. Orientasi internal bertujuan untuk penguatan organisasi dengan melakukan kegiatan pelatihan dan pengkaderan, sedangkan orientasi eksternal bertujuan mempengaruhi pemikiran keagamaan yang berkembang berdasarkan misi dan tujuan organisasi dengan melakukan berbagai kajian, seminar, dan bedah buku.

Pandangan kelompok-kelompok keagamaan menyangkut berbagai aspek ajaran Islam dan aspek kehidupan manusia dengan tidak terlepas dari faktor-faktor yang melatarbelakangi keberadaannya. Berdasarkan tematema kajian yang berkembang, kelompok-kelompok keagamaan tersebut 
dapat dibagi pada tiga kelompok: Pertama, kelompok yang semata-mata menyampaikan ajaran Islam dalam rangka untuk memberikan keseimbangan sikap dalam kehidupan ini. Kedua, kelompok yang ingin melakukan pemurnian terhadap ajaran agama berdasarkan Alquran dan hadis. Ketiga, kelompok yang ingin melakukan islamisasi seluruh kehidupan manusia, untuk membentuk suatu masyarakat berdasarkan ajaran Islam.

\section{DAFTAR PUSTAKA}

Abdullah, Taufik (ed.). Agama dan Perubahan Sosial. Jakarta: Rajawali, 1983.

Pemuda dan Perubahan Sosial. Jakarta: LP3ES, 1974.

Ali, Fachry dan B. Effendy. Politik dan Gerakan Mahasiswa Suatu Tinjauan Sejarah. Jakarta: Inti Sarana Aksara, 1985.

Daud Ali, Mohammad. Pendidikan Agama Islam. Jakarta: RajaGrafindo Persada, 1998.

Koentjaraningrat. Beberapa Pokok Antropologi Sosial. Jakarta: Dian Rakyat, 1981.

Madjid, Nurcholis. "Dialog Integral dalam Peradaban dan pemikiran Islam". Simposium Citra kampus Religius. Semarang: Universitas Islam Sultan Agung, 1985.

Rahmat A dan Nadjib M. Gerakan Perlawanan dari Mesjid Kampus. Surakarta: Purimedia, 2001.

Tisna Amidjaya, Doddy A. "Dialog Integral dalam Peradaban dan pemikiran Islam". Simposium Citra kampus Religius. Semarang: Universitas Islam Sultan Agung, 1985.

Mukhlis dan Kathryn Robinson. Agama dan Realitas Sosial. Ujung Pandang: Lembaga Penerbitan Universitas Hasanuddin, 1985.

O'dea, Thomas F. Sosiologi Agama, Suatu Pengenalan Awal. Jakarta: Rajawali Pers, 1992. 
Robertson, Roland (ed.). Agama dalam Analisa dan Interpretasi Sosiologis. Jakarta: RajaGrafindo Persada, 1993.

Soekanto, Soerjono. Sosiologi, Suatu Pengantar. Jakarta: Rajawali, 1986.

Sumardi, Mulyanto. Penelitian Agama, Masalah dan Pemikiran. Jakarta: Sinar Harapan, 1982.

Suparlan, Parsudi. Pengetahuan Budaya, llmu-Ilmu Sosial dan Pengkajian Masalah-Masalah Agama. Jakarta: Balitbang Agama Depag., 1981/1982.

Zaman, Ali Noer. Agama Untuk Manusia. Yogyakarta: Pustaka Pelajar, 2000. 